\title{
UJECIE SPOŁECZNE I PRAWNE EUROPEJSKICH RAD ZAKŁADOWYCH NA PODSTAWIE WŁASNYCH BADAŃ EMPIRYCZNYCH. I CZĘŚĆ
}

\author{
Grażyna Spytek-Bandurska \\ Uniwersytet Warszawski \\ Wydział Nauk Politycznych i Studiów Międzynarodowych \\ ORCID ID: https://orcid.org/0000-0002-7346-0185 \\ e-mail: gspytek-bandurska@wp.pl
}

\begin{abstract}
Streszczenie: Celem artykułu złożonego z dwóch części jest przedstawienie wybranych aspektów dotyczących oceny funkcjonowania europejskich rad zakładowych w krajach członkowskich UE na podstawie wyników własnych badań empirycznych. Chodzi o pokazanie mocnych i słabych stron tych instytucji dialogu społecznego oraz wskazanie rekomendacji służących ich wzmocnieniu, aby mogły one lepiej realizować prawo do informacji i konsultacji. W pierwszej części są zaprezentowane ogólne opinie o ERZ i ich potencjał w ocenie respondentów. Natomiast druga część jest poświęcona zagadnieniom wymagającym poprawy.
\end{abstract}

Słowa kluczowe: Europejskie rady zakładowe (ERZ), dialog społeczny, informowanie, konsultacja, przedsiębiorstwo międzynarodowe, pracownicy, związki zawodowe

Europejskie rady zakładowe (ERZ) są odpowiedzią na postulaty ustanowienia mechanizmów ponadnarodowego informowania i przeprowadzania konsultacji z pracownikami w Unii Europejskiej stanowiąc rezultat dążeń integracyjnych, demokratyzacji stosunków przemysłowych i budowy dialogu w ramach zrównoważonego rozwoju gospodarczego (Rudolf 1999). Za ich pośrednictwem kierownictwo centralne przedsiębiorstwa międzynarodowego ma przekazywać informacje załodze o wszelkich sprawach mających dla niej znaczenie oraz konsultować je w celu zapewnienia skuteczności praw i zachowania pokoju społecznego w każdym kraju, gdzie prowadzi swoją działalność (Stelina 2011). Rolą ERZ jest ułatwienie wymiany wiedzy i opinii na temat przedsięwzięć pracodawcy podejmowanych na szczeblu wspólnotowym oraz utrzymanie synergii między pracownikami zatrudnionymi w dwóch lub kilku krajach członkowskich, zwłaszcza w kwestiach kluczowych mających wpływ na wielkość i strukturę załogi (np. 
restrukturyzacje, obniżanie kosztów pracy, planowanie inwestycji, wdrażanie nowych technologii i metod zarządzania). Dzięki ERZ następuje budowa zaufania, poszukiwanie zrozumienia, a nawet angażowanie pracowników w wyzwania stojące przed wielonarodowym przedsiębiorstwem związane z rosnącą konkurencją, cyfryzacją, globalizacją i zmianami demograficznymi. Wyjaśniane są problemy, co ma sprzyjać zapobieganiu negatywnym ich skutkom oraz przyczyniać się do ochrony praw i interesów pracowniczych (Wratny 2006).

Głównym aktem tworzącym obecnie fundamenty zinstytucjonalizowanego dialogu społecznego w wymiarze europejskim jest dyrektywa 2009/38/WE z dnia 6 maja 2009 r. w sprawie ustanowienia europejskiej rady zakładowej lub trybu informowania pracowników i konsultowania się z nimi w przedsiębiorstwach lub w grupach przedsiębiorstw o zasięgu wspólnotowym, która umocniła rozwój ponadnarodowych stosunków pracy zapewniając skuteczność, spójność i pewność prawa przez powiązanie uregulowań unijnych z ustawodawstwem lub praktyką krajową. Mimo pozytywnego jej oddziaływania przez danie impulsu do tworzenia ERZ oraz renegocjacji istniejących umów, nie powstrzymała tendencji spadkowej ich liczebności. W 2016 r. liczba rad wynosiła ogółem 1091, a zaangażowanych w ich funkcjonowanie było 15-20 tys. przedstawicieli pracowników. Działały one przede wszystkim w przedsiębiorstwach z siedzibą we Francji, Stanach Zjednoczonych, Szwecji, Niemczech i Wielkiej Brytanii ze względu na wielkość i światowy zasięg koncernów oraz powszechność w tych państwach prawa układowego (Europejskie Rady Zakładowe 2016). Chociaż dyrektywa zwiększyła przejrzystość ram prawnych i wpłynęła na wzrost świadomości w temacie partycypacji, to jednak nie zdołała pokonać wielorakich i złożonych barier. Wynikały one często z ambiwalentnych postaw pracodawców, zmieniającej się wielkości i struktury przedsiębiorstw powodując niespełnianie kryterium wymaganego do ustanowienia ponadnarodowej procedury informowania i konsultacji, posiadania siedziby w krajach o słabo rozwiniętej tradycji dialogu społecznego, które hamowały powstawanie lub umacnianie istniejących ERZ.

W celu weryfikacji tezy o dokonującym się postępie i wzmacnianiu siły oddziaływania coraz większej liczby ERZ wobec ogólnie panującego przekonania o regresie tych instytucji zostały przeprowadzone własne badania empiryczne, które miały pokazać ich mocne i słabe strony oraz określić katalog działań niezbędnych do wdrożenia, żeby zdołały poprawić swoją sytuację, albowiem odgrywają one ważną rolę w integracji państw członkowskich UE i tworzenia jednolitego rynku. W obliczu wyzwań gospodarczych, których zakres uległ rozszerzeniu wskutek niespodziewanego pojawienia się pandemii COVID-19 i powodowanego nią kryzysu ekonomicznego, a także narastających problemów ekologicznych, demograficznych i technologicznych zaangażowanie pracowników ma strategiczne znaczenie dla zarządzania zmianami w przedsiębiorstwach, kiedy nieuchronne są przeobrażenia dotyczące organizacji pracy oraz restrukturyzacje.

Badania empiryczne stanowiły komponent międzynarodowego projektu pt. „Start and Go! Partnerzy społeczni w kierunku skutecznych procesów tworzenia 
i zarządzania Europejskimi Radami Zakładowymi” (VS/2020/0108) realizowanego w okresie 2020-2021, którego grantodawcą była Komisja Europejska, Directorate-General for Employment, Social Affairs and Inclusion. Były one prowadzone w czterech krajach: Polsce, Portugalii, Hiszpanii i Słowacji. Badania miały charakter poznawczy i eksploracyjny, oparty na metodzie indukcyjnej (bottom-up) polegającej na zaobserwowaniu konkretnych zjawisk w zakresie dialogu społecznego i zbiorowych stosunków pracy, a następnie analitycznym opracowaniu stanowisk teoretycznych. Behawioralne oraz komparatystyczne podejście metodologiczne miało potwierdzać interdyscyplinarność i wielowątkowość tematyki projektu. W ramach celów szczegółowych związanych z tezą główną chodziło o: zdiagnozowanie potencjału tworzenia oraz wzmacniania funkcjonujących ERZ; identyfikację barier oraz niewykorzystanych szans rozwoju ERZ; wydajności i skuteczności działania; przestrzeni do poprawy ERZ; potrzeb członków; określenie roli partnerów społecznych we wspieraniu procesu wdrażania ERZ oraz kształtowania relacji z zarządem centralnym w międzynarodowych korporacjach mających swoją siedzibę główną lub oddziały w analizowanych krajach. Metoda pracy była nakierowana na osiągnięcie postawionych zamierzeń cząstkowych umożliwiających kompleksowe podejście do ERZ i określenie ich sprawczości na tle całokształtu spraw dotyczących europejskiego filaru socjalnego, w tym wykonalności prawa do ponadnarodowej informacji i konsultacji. Przyjęta koncepcja metodologiczna uwzględniająca analizę ilościową opartą na badaniach ankietowych oraz jakościową w postaci pogłębionych wywiadów indywidualnych miała przyczynić się do pogłębienia stanu wiedzy.

Badania w każdym kraju wykonali eksperci wyznaczeni przez partnerów projektu, to jest reprezentatywne związki zawodowe i organizacje pracodawców. Podstawowym narzędziem był kwestionariusz ankiety wysyłany online do respondentów (metoda CAWI). Założono dotarcie do przynajmniej 100 osób, co udało się osiągnąć w przypadku Polski, Słowacji i prawie Portugalii. Najmniejszy odsetek był w Hiszpanii. Mimo ponawiania badań nie uzyskano wymaganej liczby ankietowanych, co należy tłumaczyć trudną w tym czasie sytuacją spowodowaną pandemią COVID-19. Ogółem udzielono 354 odpowiedzi. W drugim etapie zostały zrealizowane wywiady. Łącznie badaniem z 4 krajów objęto 66 osób, których skala spełniła zakładane minimum. Dobór próby był celowy. Grupę respondentów stanowili członkowie ERZ lub specjalnego zespołu negocjacyjnego, liderzy związków zawodowych i pracodawcy reprezentujący przedsiębiorstwa należące do sekcji przetwórstwa przemysłowego z branż: motoryzacyjnej, spożywczej, metalurgicznej, chemicznej, elektrotechnicznej, w których są ERZ lub nie zostały one ustanowione, mimo spełniania kryteriów formalnych.

Po zebraniu kwestionariuszy eksperci dokonali przetworzenia zebranych danych, zgodnie z zasadami gromadzenia, kodowania i analizowania wyników, a następnie przygotowali według ustalonego schematu raport krajowy. Ujednolicona prezentacja uzyskanych danych statystycznych i przedstawione na ich podstawie wnioski pozwoliły przybliżyć problematykę ERZ w każdym kraju i dokonać międzynarodowej analizy porównawczej w opracowaniu końcowym. 


\section{OPINIE RESPONDENTÓW O ERZ}

Dokonując analizy opinii na temat ERZ należy zauważyć, że są one zróżnicowane w odniesieniu do kraju pochodzenia respondentów. O zaawansowaniu prerogatyw zarówno proceduralnych, jak i merytorycznych świadczą: kraj siedziby centralnej przedsiębiorstwa, stopień umiędzynarodowienia, obowiązujący porządek prawny, tradycja i kultura dialogu, sytuacja społeczno-gospodarcza, typ przedstawicielstwa pracowniczego, długość istnienia i doświadczenie ERZ. Najlepsze oceny wystawili respondenci słowaccy $(78 \%)$ w przeciwieństwie do hiszpańskich wyrażających przede wszystkim niezadowolenie (44\%). Dobre opinie przeważały wśród portugalskich i polskich ankietowanych (odpowiednio $52 \%$ i $46 \%$ ) w porównaniu do złych (ponad 4\%), których najwięcej zgłaszali badani z Hiszpanii (16\%). Na pytanie o przyczyny pozytywnego stanowiska wskazywano, że ERZ stanowią autentyczne wsparcie dla pracowników w informowaniu i konsultacjach, gdyż mają duży wpływ na decyzje podejmowane przez zarząd centralny, przyczyniają się do załatwiania spraw pomijanych na szczeblu krajowym, zabiegają o podnoszenie (wyrównywanie) standardów pracy. Dzięki korzystnie skonstruowanym porozumieniom i przyznanym uprawnieniom mogą one sprawnie i efektywnie działać. Atutem jest regularność i większa częstotliwość spotkań z udziałem zarządu centralnego, rzetelność i wielość danych przekazywanych z odpowiednim wyprzedzeniem, wymiana doświadczeń i dobrych praktyk, współpraca z zagranicznymi przedstawicielami pracowników, udział ekspertów i tłumaczy, rozwijanie kompetencji członków ERZ przez zapewnianie im szkoleń stosownie do zgłaszanych potrzeb. Prowadzone na forum dyskusje są merytoryczne i konstruktywne, ponieważ umożliwiają wnikliwe zapoznanie się ze sprawą i potem wdrażanie ulepszeń. Dialog odbywa się z poszanowaniem stron, gwarantowana jest transparentność, otwartość i równość. Poza sprawną organizacją ERZ wartością dodaną jest w wielu przypadkach wyższa liczebność członków w porównaniu do wymogów prawa powszechnego. Natomiast o negatywnych ocenach przesądzają uwagi pod adresem pracodawców, których postawy niechętne wobec partycypacji pracowniczej skutkują nietworzeniem ERZ bądź osłabieniem ich aktywności. W rezultacie nie dochodzi do wymiany informacji i konsultacji albo jest ona pozorowana, wybiórcza, często następuje z opóźnieniem, gdy stanowisko zarządu centralnego jest już przesądzone, a nawet upublicznione. Innym przykładem jest obejmowanie informacji klauzulą poufności, mimo że nie ma podstaw do jej zastosowania albo ogólnikowość treści, pomijanie w dyskusji kwestii kluczowych związanych z warunkami i stabilnością zatrudnienia. Posiedzenia ERZ są sporadyczne i nie zawsze w pełnym składzie. Odbywają się zdalnie (wideokonferencje), co nie sprzyja współpracy. Barierą w budowaniu autentycznego partnerstwa jest traktowanie ERZ jako uciążliwego obowiązku, a nie forum współpracy. Brakuje poczucia sprawczości i oddziaływania na proces decyzyjny. Członkowie z różnych krajów nie są równo traktowani. Pracodawca kieruje się partykularnym interesem i nie zawsze wywiązuje z porozumień bądź 
przedłuża procedurę ich zawarcia. Zdarza się, że nie zapewnia środków pozwalających ERZ sprawnie funkcjonować (wyposażenie, narzędzia komunikacji) oraz zwiększać stopień profesjonalizmu (szkolenia, ekspertyzy). Obecna sytuacja wywołana pandemią COVID-19 nie ułatwia wzmocnienia pozycji ERZ.

Na Słowacji przeważały pozytywne opinie, mimo uwag krytycznych i niezbyt dużego doświadczenia ujawniającego rzeczywiste funkcjonowanie tych instytucji dialogu, choć respondenci zastrzegli, że czas pokaże, czy w dłuższej perspektywie nie nastąpi zmiana ich podejścia. Mocne i słabe strony ERZ zostały równomiernie przedstawione w badaniach polskich i portugalskich respondentów. Natomiast sceptyczne głosy wyrażono w Hiszpanii wskutek bardzo trudnej sytuacji na rynku pracy i ogólnego zaniepokojenia rosnącym bezrobociem. Pandemia silnie wpłynęła na pogorszenie stanu gospodarczego kraju i osłabienie kondycji przedsiębiorstw międzynarodowych, co przełożyło się na negatywne nastroje społeczne. Hiszpańscy przedstawiciele pracowników zwrócili uwagę na pomijanie dialogu społecznego w rozstrzyganiu spraw dotyczących zatrudnienia, głównie utrzymania miejsc pracy.

Jednolite stanowisko respondentów dotyczyło ogólnego przez nich postrzegania ERZ w państwach członkowskich Unii Europejskiej. Badani byli zgodni, że pełnią one rolę organów informacyjnych i doradczych, które osiągnęły pozycję znaczącego partnera społecznego, głównie w krajach o długiej tradycji partycypacyjnej. Jako ważny przedstawiciel pracowników biorą udział w dialogu prowadzonym z pracodawcami w sprawach dotyczących funkcjonowania transnarodowych przedsiębiorstw. Znaczenie ERZ wzrasta wskutek ogólnych zjawisk, jakie coraz silniej oddziałują na dekompozycję dotychczasowych stosunków przemysłowych w Europie, to jest globalizacji, rosnącej konkurencji, przeobrażeń w gospodarce opartej na wiedzy i nowych technologiach oraz dążeń do utrzymania spójności społecznej. Zachodzące na rynku wewnętrznym zmiany obejmujące procesy łączenia lub przejmowania przedsiębiorstw, fuzji transgranicznych, a także podejmowanie wspólnych przedsięwzięć umiędzynaradawiających działalność gospodarczą wymagają zapewnienia harmonijnego rozwoju i ładu społecznego. Dlatego tak ważne jest tworzenie organów reprezentacji pracowniczej, aby załogom przedsiębiorstw o zasięgu wspólnotowym zapewnić udział w tworzeniu nowego ładu korporacyjnego poprzez informowanie i konsultowanie. $Z$ tymi twierdzeniami utożsamiali się przede wszystkim respondenci wywodzący się ze struktur związkowych.

\section{POTENCJAE ERZ}

Na pytanie o rzeczywistą rolę ERZ, do których przynależą respondenci, większość z nich uznała, że jest ona aktywna w procesie informacji i konsultacji, szczególnie na Słowacji. Jedynie w Hiszpanii przeważyły wypowiedzi przeciwne, wskazujące na fasadowość i symboliczne znaczenie ERZ. Aspektem wpływają- 
cym na efektywność prac tych instytucji są posiadane przez samych członków kompetencje. Spośród podanego katalogu atutów respondenci najczęściej podkreślali wiedzę fachową ( $65 \%$ - Portugalia), komunikatywność, w tym znajomość języków obcych (66\% - Słowacja), bogate doświadczenie (48\% - Polska). Spore znaczenie przypisywano osiągnięciom (aktywności) w związkach zawodowych, które są uważane za gremia przedstawicielskie najskuteczniej chroniące interesy załogi (66\% - Polska, 57\% - Portugalia). Respondenci podkreślali, że zdecydowanie łatwiej ERZ radzą sobie z informowaniem i prowadzeniem konsultacji, jeśli członkowie posiadają te zdolności.

Sprawność działania, przejrzystość procedur, istnienie zaplecza w postaci ekspertów i tłumaczy, możliwość tworzenia komitetów, zespołów doradczych lub innych form wsparcia, prowadzenie dialogu wertykalnego (między poziomem krajowym i ponadnarodowym), posiadanie renomy w środowisku pracowniczym, to główne czynniki funkcjonowania ERZ świadczące o ich potencjale. To pozwala potwierdzić tezę, że wzrost znaczenia wszelkich typów partycypacji nie jest wyłącznie wynikiem uchwalenia nowych regulacji prawnych, lecz wieloletnim budowaniem więzi społecznych. Zdaniem badanych ważne są dobre praktyki, albowiem proces doskonalenia ERZ jest w dużej mierze zależny od czynnika ludzkiego. Semiimperatywny charakter przepisów powinien pełnić funkcję pomocniczą w kształtowaniu wzajemnych relacji. Niebagatelną rolę odgrywa podejście kierownictwa przedsiębiorstwa (centralnego, lokalnego). W kontekście nieprawidłowości, jakie występowały na przestrzeni ostatnich lat, sytuacja poprawiła się po implementacji dyrektywy 2009/38/WE. Dostrzegalne są dwa rodzaje sankcjonowania procedury do informacji i konsultacji. $\mathrm{Z}$ jednej strony kierownictwo zachowuje się neutralnie, a więc traktuje ERZ w kategoriach obowiązku nałożonego przez prawo i podejmuje czynności wyłącznie w wymaganym zakresie. $Z$ drugiej zaś działa proaktywnie wychodząc poza minimum i spełniając oczekiwania pracowników. Swój pozytywny stosunek do tej formy partycypacji racjonalizuje współczesnymi metodami zarządzania i procesami konkurencyjnymi po stronie popytowej, które mobilizują do dbałości o pracowników, zwłaszcza wykwalifikowanych bądź stanowiących deficytowy zasób w pewnych sektorach, między innymi poprzez umożliwianie im rzeczywistego i skutecznego uczestnictwa w sprawach przedsiębiorstwa. W opinii blisko $70 \%$ respondentów z Hiszpanii i połowy z Polski zarząd centralny przedsiębiorstwa postrzega ERZ w sposób neutralny jako wymóg prawa, który należy w niezbędnym zakresie spełnić. Podobnego zdania było ponad 52\% słowackich badanych, którzy wskazali na neutralne lub negatywne stanowisko jako dodatkowe obciążenie spowalniające procesy decyzyjne pracodawcy. Taką też oceną podzielili się w $66 \%$ portugalscy respondenci. Do podejścia pozytywnego zarządu centralnego uznającego, że powinna istnieć instytucja dialogu, szeroka platforma komunikacji i wypracowywania dobrych praktyk było przekonanych najwięcej badanych z Polski oraz Słowacji-odpowiednio 25\% i 21\%. Wyrazili oni średnio więcej ocen korzystnych dotyczących różnych aspektów funkcjonowania ERZ. 
Respondenci zwracali uwagę na możliwości oddziaływania związków zawodowych, które korzystając z różnych metod interwencji i nagłaśniania problemów potrafią skłonić kierownictwo do działań w celu stworzenia transnarodowego modelu dialogu. Partnerzy społeczni są coraz bardziej świadomi, że w obliczu negatywnych zmian na rynku, kiedy z powodów ekonomicznych nie da się wyhamować pewnych procesów (restrukturyzacje, obniżanie kosztów pracy) trzeba komunikować się i szukać kompromisów niż wybierać spór zbiorowy i strajki. Konflikt nie jest dobrym rozwiązaniem, bo trudniej rozwiązuje się problemy i szkodzi ogólnemu wizerunkowi. Zatem niewłaściwe zachowania działają na niekorzyść obu stron. Nieprzychylność i protesty pracowników mogą zniechęcać do inwestowania, a uchylanie się od przyjętych ogólnie standardów socjalnych prowadzić do utraty wykwalifikowanej kadry.

Według badanych następuje zmiana postaw związków zawodowych i sposobu rozumienia wyzwań współczesnego świata. Są one coraz bardziej świadome następstw globalizacji i wiedzą, że decyzje podejmowane w jednym kraju wpływają na sytuację w innych, gdzie działa przedsiębiorstwo transnarodowe. Hiszpańscy respondenci podkreślali, że zachodzi pewien paradoks wewnątrzzwiązkowy między solidarnością a rywalizacją, gdyż przedstawiciele organizacji związkowych mają na forum wspólnotowym jednoczyć się i wspólnie występować wobec zarządu centralnego, a zarazem pokazują swój partykularyzm, bo oddzielnie dążą do utrzymania zatrudnienia i godnych warunków pracy na szczeblu krajowym. Inną kwestią jest reprezentatywność. Po stronie związkowej powinna zachodzić względna równowaga, aby mniejsze organizacje mogły mieć faktyczny wpływ na kształtowanie ERZ oraz ustalanie trybu informowania i konsultacji. Jednak inaczej uważali słowaccy badani. W przypadku rozdrobnienia reprezentacja związkowa staje się mniej efektywna. Dominująca pozycja jednej organizacji, w tym jej członkostwo w europejskich strukturach związkowych powoduje monopolizację działań i większy dostęp do wiedzy na poziomie unijnym, co przekłada się na wzrost roli ERZ. Przy braku partnerstw i łączenia się w federacje oraz wsparcia ze strony państwa trudno jest tworzyć przeciwwagę dla pracodawcy, co służy autonomii jego postępowania. Takie stanowisko zajęli też polscy respondenci.

\section{PODSUMOWANIE}

Przedstawiona w niniejszym artykule analiza wybranych zagadnień funkcjonowania ERZ oraz prezentacja roli partnerów społecznych we wspieraniu ich działania powinny stanowić wartościowy wkład do przemyśleń o aktualnym stanie i kierunkach europeizacji dialogu społecznego. Nowe spojrzenie na ERZ powinno być asumptem do dyskusji na temat przyszłości zbiorowych stosunków pracy i kształtowanego prawa zatrudnienia w gospodarce opartej na wiedzy. Chociaż otrzymane dane z badań empirycznych nie mają mocy statystycznej, to 
jednak zarysowują one pewien wycinek rzeczywistości, który wydaje się zbieżny z konkluzjami spotykanymi w literaturze przedmiotu. Wyciągnięte na ich podstawie wnioski pozwalają uznać, że dokonuje się postęp i następuje wzmocnienie siły oddziaływania części ERZ wobec ogólnie panującego przekonania o regresie tych instytucji.

Title: Social and Legal Approach of European Works Councils Based on Own Empirical Research. I Part

\begin{abstract}
The aim of the article, consisting of two parts, is to present selected aspects concerning the assessment of the functioning of European works councils in the EU Member States based on the results of own empirical research. It is about showing the strengths and weaknesses of these institutions of social dialogue and indicating recommendations to strengthen them, so that they can better implement the right to information and consultation. The first part presents general views on EWCs and their potential as assessed by the respondents. The second part, on the other hand, is devoted to issues that require improvement.
\end{abstract}

Keywords: European works councils (EWCs), social dialogue, informing, consultation, multinational company, employees, trade unions

\title{
BIBLIOGRAFIA
}

1. Europejskie Rady Zakładowe. Oceny i wymagania (2016). Sprawozdanie dla EKZZ, Bruksela.

2. Dyrektywa 2009/38/WE z dnia 6 maja 2009 r. w sprawie ustanowienia europejskiej rady zakładowej lub trybu informowania pracowników i konsultowania się z nimi w przedsiębiorstwach lub w grupach przedsiębiorstw o zasięgu wspólnotowym, OJ L 122, 16.5.2009.

3. Rudolf Stanisław (1999), Europejskie Rady Zakładowe. Konsekwencje dla Unii Europejskiej i Polski, „Studia Prawno-Europejskie”, t. 4.

4. Stelina Jakub (2011), Powoływanie Europejskiej Rady Zaktadowej w świetle prawa polskiego, "Gdańskie Studia Prawnicze”, t. XXV.

5. Wratny Jerzy (2006), Prawo pracowników do informacji i konsultacji w świetle Dyrektywy 2002/14 Wspólnoty Europejskiej, „Państwo i Prawo”, nr 8. 